\title{
Comparisons of Brightness Temperatures of Landsat-7/ETM+ and Terra/MODIS around Hotien Oasis in the Taklimakan Desert
}

\author{
Yoshinari Oguro, ${ }^{1}$ Seiji Ito, ${ }^{1}$ and Kiyoshi Tsuchiya ${ }^{2}$ \\ ${ }^{1}$ Department of Global Environment Studies, Hiroshima Institute of Technology, 2-1-1, Miyake, Saeki-ku, \\ Hiroshima 731-5193, Japan \\ ${ }^{2} J a p a n$ Meteorological Consultant Association, 6-32-10, Hirai, Edogawa-ku, Tokyo 132-0035, Japan \\ Correspondence should be addressed to Yoshinari Oguro, y.oguro.yx@it-hiroshima.ac.jp \\ Received 15 December 2010; Revised 22 February 2011; Accepted 20 March 2011 \\ Academic Editor: Michel C. Nolin
}

Copyright (๑) 2011 Yoshinari Oguro et al. This is an open access article distributed under the Creative Commons Attribution License, which permits unrestricted use, distribution, and reproduction in any medium, provided the original work is properly cited.

\begin{abstract}
The brightness temperature (BT) of Taklimakan Desert retrieved from the data of Landsat-7/ETM+ band 6 and Terra/MODIS band 31 and 32 indicates the following features: (1) good linear relationship between the BT of ETM+ and that of MODIS, (2) the observation time adjusted BT of ETM+ is almost equal to that of MODIS, (3) the BT of Terra/MODIS band 31 is slightly higher than that of band 32 over a reservoir while opposite feature is recognized over desert area, (4) the statistical analysis of 225 sample data of ETM+ in one pixel of MODIS for different landcovers indicates that the standard deviation and range of BT of ETM+ corresponding to one pixel of MODIS are $0.45^{\circ} \mathrm{C}, 2.25^{\circ} \mathrm{C}$ for a flat area of desert, while respective values of the oasis farmland and shading side of rocky hill amount to $2.88^{\circ} \mathrm{C}, 14.04^{\circ} \mathrm{C}$, and $2.80^{\circ} \mathrm{C}, 16.04^{\circ} \mathrm{C}$.
\end{abstract}

\section{Introduction}

The brightness temperatures (BTs) retrieved from the data of thermal infrared (TIR) bands of the sensors onboard Terra, Aqua, and meteorological satellites are widely used in the study of global warning including energy flux between land surface and the atmosphere, while there are not a few demands for the BT retrieved from the TIR band of Landsat7/ETM+ (Enhanced Thematic Mapper Plus). The spatial resolution of the data of the TIR band of Landsat-7/ETM+ is approximately $60 \mathrm{~m}$ which is a great advantage for the study of meso and small scale phenomena however it is extremely difficult to get satisfactory data due to long repeat cycle of 16 days $[1,2]$. On the other hand, in case of Terra/MODIS (MODerate resolution Imaging Spectroradiometer) and Aqua/MODIS the TIR band data can be acquired almost in daily basis although the spatial resolution is approximately $1000 \mathrm{~m}[3,4]$.

For the reflective solar bands, the data of the surface reflectance of Terra/MODIS were analyzed together with the data of Landsat-7/ETM+ and confirmed that the absolute error of the land surface products was less than 5\% [5]. In addition, the intercalibration between the reflected bands of Landsat-7/ETM+ and those of Terra/MODIS was performed for the vegetation analysis [6]. Based on these analyses, it was concluded that the reflectance bands of Landsat-7/ETM+ and Terra/MODIS have good linear relationship.

For TIR bands the level-2 MODIS land surface temperature (LST) product of $1 \mathrm{~km}$ spatial resolution (MOD11_L2) obtained from the TIR bands 31 and 32 of Terra/MODIS it was confirmed that the error of LST products ranging from $263 \mathrm{~K}\left(-10^{\circ} \mathrm{C}\right)$ to $322 \mathrm{~K}\left(49^{\circ} \mathrm{C}\right)$ is less than $1 \mathrm{~K}$ for the atmospheric column water vapor ranging from 0.4 to $3.0 \mathrm{~cm}$ [3]. Furthermore it was also confirmed that the error of the daily level-3 MODIS LST product of $1 \mathrm{~km}$ spatial resolution (MOD11A1 Version 5 for Terra and MYD11A1 Version 5 for Aqua) obtained from the same bands of both Terra and Aqua/MODIS was less than $1 \mathrm{~K}$ in the range from $263 \mathrm{~K}$ $\left(-10^{\circ} \mathrm{C}\right)$ to $331 \mathrm{~K}\left(58^{\circ} \mathrm{C}\right)$ for the atmospheric column water vapor ranging from 0.4 to $3.5 \mathrm{~cm} \mathrm{[7].}$

The objective of this paper is to compare the BT of selected targets of Taklimakan Desert in China observed with 
TABLE 1: Satellite specification of Landsat-7 and Terra.

\begin{tabular}{|c|c|c|c|c|c|c|c|}
\hline Satellite & Sensor & Launch date & $\begin{array}{c}\text { Altitude } \\
(\mathrm{km})\end{array}$ & $\begin{array}{c}\text { Inclination } \\
\text { (degrees) }\end{array}$ & $\begin{array}{c}\text { Swath } \\
(\mathrm{km})\end{array}$ & $\begin{array}{c}\text { Repeat cycle } \\
\text { (days) }\end{array}$ & $\begin{array}{c}\text { Crossing time } \\
\text { (UTC) }\end{array}$ \\
\hline Landsat-7 & ETM+ & April 15, 1999 & 705 & 98.2 & 185 & 16 & $\begin{array}{c}\text { 10:00-10:15 } \\
\text { (Descending } \\
\text { node) }\end{array}$ \\
\hline Terra & MODIS & $\begin{array}{l}\text { December 18, } \\
1999\end{array}$ & 705 & 98.2 & 2330 & $1-2$ & $\begin{array}{c}10: 30 \\
\text { (Descending } \\
\text { node) }\end{array}$ \\
\hline
\end{tabular}

TABLE 2: Band specification of the TIR bands of Landsat-7/ETM+ and Terra/MODIS.

\begin{tabular}{lccccccc}
\hline Satellite & Sensor & Band & $\begin{array}{c}\text { Spectral range } \\
(\mu \mathrm{m})\end{array}$ & $\begin{array}{c}\text { For spectral range } \\
(\mu \mathrm{m})\end{array}$ & $\begin{array}{c}\text { For cumulative } \\
\text { histogram at } 50 \% \\
\text { of RSR }(\mu \mathrm{m})\end{array}$ & $\begin{array}{c}\text { Spectral } \\
\text { radiance } \\
\left(\mathrm{W} /\left(\mathrm{m}^{2} \cdot \mathrm{sr} \cdot \mu \mathrm{m}\right)\right)\end{array}$ & $\begin{array}{c}\text { Spatial } \\
\text { resolution } \\
(\mathrm{m})\end{array}$ \\
\hline Landsat-7 & ETM+ & 6 & $10.31-12.36$ & 11.335 & 11.217 & $8.20(\mathrm{LG})$ & $6.09(\mathrm{HG})$ \\
\hline Terra & MODIS & 31 & $10.78-11.28$ & 11.030 & 11.011 & $9.55(300 \mathrm{~K})$ & 60 \\
12 & $11.77-12.27$ & 12.020 & 12.027 & $8.94(300 \mathrm{~K})$ & 1000 \\
\hline
\end{tabular}

Note that LG and HG for Landsat-7/ETM+ indicate the low gain and the high gain, respectively.

the TIR bands of Landsat-7/ETM+ and Terra/MODIS and to clarify the relationship between the BT obtained from both sensors.

\section{Analysis Data and Study Area}

2.1. Data Analysis. The specification of Landsat-7 [2] and Terra [4] is shown in Table 1, which indicates that the orbits of two satellites are almost same and the observation time difference is within 30 minutes. The specification of TIR band of Landsat-7/ETM+ and Terra/MODIS is shown in Table 2. The relative spectral response (RSR) of band 6 (TIR band) of ETM+ $[1,2,5]$ and bands 31 and 32 of MODIS $[4,8]$ is shown in Figure 1. The separation of RSR of MODIS band 31 and 32 is good which suggests the effectiveness of split-window (SW) method [9] to retrieve BT of the land surface. The major difference of two sensors is spatial and spectral resolution, swath width, and repeating cycle.

The instrument malfunction occurred on the Scan Line Corrector (SLC) of Landsat-7/ETM+ on May 31, 2003 subsequently SLC was turned off, and now only SLC-off mode data are acquired $[2,10]$. In this study, we decided to analyze SLC-on mode data of ETM+ acquired before May 31,2003 . To reduce the shading effects on the BT of the land surface of vegetated area the data of higher sun elevation were selected.

2.2. Study Area. The study area is around Hotien Oasis of the southwestern part of Taklimakan Desert in XinJiang, China. Covering the area between $74^{\circ} \mathrm{E}$ and $96^{\circ} \mathrm{E}, 36^{\circ} \mathrm{N}$ and $43^{\circ} \mathrm{N}$ Taklimakan Desert is the largest sandy desert in Asia with the area of about $270,000 \mathrm{~km}^{2}[11,12]$. The main reasons of having chosen the area are
(1) During a fairly large-scale research project "JapanChina Joint Study on Desertification (1989-1994)", using a hand-held radiometer we have collected abundantly the land surface and underground temperature data of this area together with near surface meteorological data and also radio sounding data.

(2) Surrounded by high mountain ranges with average height of 1200 meter above sea level the area is characterized with extremely dry atmospheric condition resulting in very little effect of water vapor.

(3) Locating between two rivers, the Karakax River and the Yurungkax River, Hotien Oasis is the largest oasis in the southern part of the desert $[13,14]$. There is a good weather station equipped with radio sounding facilities, land surface, and underground temperature observing facilities. This area was one of the major target areas of concentrated observation during the joint study.

The analyzed satellite data of Landsat-7/ETM+ and Terra/MODIS over and around Hotien Oasis are shown in Table 3, while the false color images of Landsat-7/ETM+ (R, B, G: bands 4, 3, and 2) and Terra/MODIS (R, G, B: bands 7, 2, and 1) over the Hotien Oasis in Taklimakan Desert observed on June 8, 2002 are shown in Figure 2. In addition, the observation areas of Landsat-7/ETM+ and Terra/MODIS are shown in Figure 3. The range of sensor nadir angles of Landsat-7/ETM+ is approximately ranging from $7.28^{\circ}$ (west) to $7.28^{\circ}$ (east) and that of Terra/MODIS is approximately ranging from $9.51^{\circ}$ (west) to $8.09^{\circ}$ (east). Furthermore, the data of meteorological observation of Hotien station is shown in Table 4. 
TABle 3: Analyzed data of Landsat-7/ETM+ and Terra/MODIS over the Hotien Oasis in Taklimakan Desert.

\begin{tabular}{|c|c|c|c|c|c|c|c|}
\hline Satellite & Sensor & $\begin{array}{l}\text { Product } \\
\text { type }\end{array}$ & $\begin{array}{c}\text { Acquisition } \\
\text { date }\end{array}$ & Scene ID & $\begin{array}{l}\text { Scan time } \\
\text { (UTC) }\end{array}$ & $\begin{array}{c}\text { Sun } \\
\text { azimuth } \\
\text { (degrees) }\end{array}$ & $\begin{array}{c}\text { Sun } \\
\text { elevation } \\
\text { (degrees) }\end{array}$ \\
\hline Landsat-7 & ETM+ & Level $1 \mathrm{~T}$ & June 8, 2002 & $\begin{array}{c}\text { 146-034 } \\
\text { (Path-Row) }\end{array}$ & $\begin{array}{c}\text { 05:05:01 } \\
\text { (Scene center) }\end{array}$ & 119.65 & 65.23 \\
\hline Terra & MODIS & MOD021KM & June 8, 2002 & $\begin{array}{c}13148 \\
\text { (Orbit number) }\end{array}$ & 05:35-05:40 & $130.56-135.53$ & $69.51-70.61$ \\
\hline
\end{tabular}

TABLE 4: The metrological observation on June 8, 2002 at the Hotien station (ID: ZWTN).

\begin{tabular}{|c|c|c|c|c|c|c|}
\hline Time & $\begin{array}{l}\text { Pressure } \\
(\mathrm{hPa})\end{array}$ & $\begin{array}{l}\text { Air temperature } \\
\left({ }^{\circ} \mathrm{C}\right)\end{array}$ & $\begin{array}{c}\text { Relative } \\
\text { humidity } \\
(\%)\end{array}$ & $\begin{array}{c}\text { Perceptible } \\
\text { water } \\
(\mathrm{mm})\end{array}$ & $\begin{array}{l}\text { Visibility } \\
(\mathrm{km})\end{array}$ & $\begin{array}{l}\text { Wind } \\
\text { speed } \\
(\mathrm{km} / \mathrm{h})\end{array}$ \\
\hline $00 \mathrm{Z}$ & 858 & 21.2 & 28 & 15.28 & - & - \\
\hline $12 \mathrm{Z}$ & 851 & 35.2 & 28 & 6.76 & - & - \\
\hline- & $\begin{array}{l}854.3 \\
\text { (Mean) }\end{array}$ & $\begin{array}{c}27.9 \text { (Mean) } \\
20.1 \text { (Min.) } \\
35.8 \text { (Max.) }\end{array}$ & $\begin{array}{c}21 \\
\text { (Mean) }\end{array}$ & $\begin{array}{c}0 \\
\text { (Precipitation } \\
\text { amount) }\end{array}$ & $\begin{array}{c}15 \\
\text { (Mean) }\end{array}$ & $\begin{array}{l}10.7 \text { (Mean) } \\
14.4 \text { (Max.) }\end{array}$ \\
\hline
\end{tabular}

Note that international station number $51828,37.13^{\circ} \mathrm{N}, 79.93^{\circ} \mathrm{E}$, and $1375 \mathrm{~m}$ (above sea level).

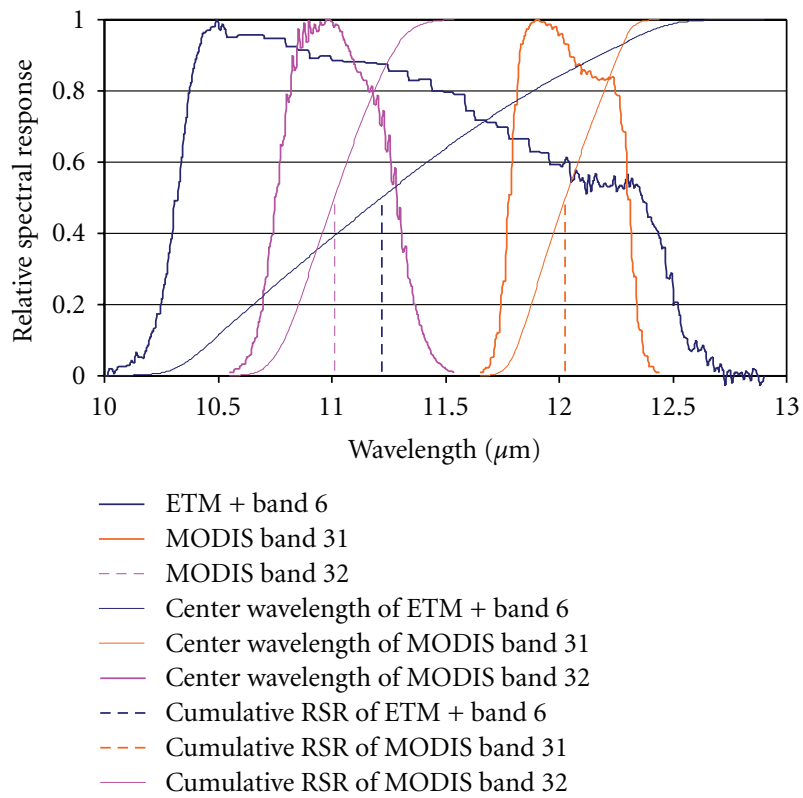

FIgure 1: Characteristics of band 6 of ETM+, Terra MODIS bands 31 and 32 .

\section{Data Processing}

3.1. Conversion of Landsat-7/ETM+ Band 6 Data to BT. Conversion of calibrated digital numbers $\left(Q_{\text {cal }}\right)$ of Landsat7/ETM+ Level-one Terrain-corrected (L1T) products back to observed spectral radiance $\left(L_{\lambda}\right)$ requires the minimum and maximum limit of the original rescaling factors $L_{\min \lambda}$ and $L_{\max \lambda}$. The pre-launch calibration constants of the TIR band 6 of Landsat-7/ETM+ for converting $Q_{\text {cal }}$ to observed spectral radiance are shown in Table 5. The conversion equation $[2,15]$ is

$$
\begin{aligned}
L_{\lambda} & =\left(\frac{L_{\max \lambda}-L_{\min \lambda}}{Q_{\text {calmax }}-Q_{\text {calmin }}}\right)\left(Q_{\text {cal }}-Q_{\text {calmin }}\right)+L_{\min \lambda} \\
& =G_{\text {rescale }} \times Q_{\text {cal }}+B_{\text {rescale }}, \\
G_{\text {rescale }} & =\left(\frac{L_{\max \lambda}-L_{\min \lambda}}{Q_{\text {calmax }}-Q_{\text {calmin }}}\right), \\
B_{\text {rescale }} & =L_{\min \lambda}-\left(\frac{L_{\max \lambda}-L_{\text {min } \lambda}}{Q_{\text {calmax }}-Q_{\text {calmin }}}\right) Q_{\text {calmin }},
\end{aligned}
$$

where $L_{\lambda}$ is observed spectral radiance in $\mathrm{W} /\left(\mathrm{m}^{2} \cdot \mathrm{sr}\right.$. $\mu \mathrm{m}), Q_{\text {cal }}$ is quantized calibrated pixel value in digital numbers of 8 bits unsigned integer data, $Q_{\text {calmin }}$ is minimum quantized calibrated pixel value corresponding to $L_{\min \lambda} \lambda$, $Q_{\text {calmax }}$ is maximum quantized calibrated pixel value corresponding to $L_{\max \lambda}, L_{\min \lambda}$ is observed spectral radiance scaled to $Q_{\text {calmin }}$ in $\mathrm{W} /\left(\mathrm{m}^{2} \cdot \mathrm{sr} \cdot \mu \mathrm{m}\right), L_{\max \lambda}$ is observed spectral radiance scaled to $Q_{\text {calmax }}$ in $\mathrm{W} /\left(\mathrm{m}^{2} \cdot \mathrm{sr} \cdot \mu \mathrm{m}\right), G_{\text {rescale }}$ is band-specific rescaling gain factor in $\mathrm{W} /\left(\mathrm{m}^{2} \cdot \mathrm{sr} \cdot \mu \mathrm{m}\right)$, and $B_{\text {rescale }}$ is band-specific rescaling bias factor in $\mathrm{W} /\left(\mathrm{m}^{2} \cdot \mathrm{sr} \cdot \mu \mathrm{m}\right)$.

The data of the TIR band 6 of Landsat-7/ETM+ can be converted from observed spectral radiance $\left(L_{\lambda}\right)$ to observed BT. The conversion equation $[2,15]$ is

$$
T_{6}=\frac{K_{2}}{\ln \left(\left(K_{1} / L_{\lambda}\right)+1\right)},
$$

where $T_{6}$ is observed BT in Kelvin, $K_{1}$ is calibration constant $1\left(666.09 \mathrm{~W} /\left(\mathrm{m}^{2} \cdot \mathrm{sr} \cdot \mu \mathrm{m}\right)\right), K_{2}$ is calibration constant $2(1282.71 \mathrm{~K})$ and $L_{\lambda}$ is observed spectral radiance in $\mathrm{W} /\left(\mathrm{m}^{2} \cdot \mathrm{sr} \cdot \mu \mathrm{m}\right)$. 
TABLE 5: Calibration constants of the TIR band of Landsat-7/ETM+ for converting calibrated digital numbers to observed spectral radiance.

\begin{tabular}{lcccc}
\hline Band & $\begin{array}{c}L_{\max \lambda} \\
\left(\mathrm{W} /\left(\mathrm{m}^{2} \cdot \mathrm{sr} \cdot \mu \mathrm{m}\right)\right)\end{array}$ & $\begin{array}{c}L_{\min \lambda} \\
\left(\mathrm{W} /\left(\mathrm{m}^{2} \cdot \mathrm{sr} \cdot \mu \mathrm{m}\right)\right)\end{array}$ & $\begin{array}{c}G_{\text {rescale }} \\
\left(\mathrm{W} /\left(\mathrm{m}^{2} \cdot \mathrm{sr} \cdot \mu \mathrm{m}\right) / Q_{\text {cal }}\right)\end{array}$ & $\begin{array}{c}B_{\text {rescale }} \\
\left(\mathrm{W} /\left(\mathrm{m}^{2} \cdot \mathrm{sr} \cdot \mu \mathrm{m}\right)\right)\end{array}$ \\
\hline 6 (Low gain) & 0.0 & 17.04 & 0.067087 & -0.07 \\
6 (High gain) & 3.2 & 12.65 & 0.037205 & 3.16 \\
\hline
\end{tabular}

Note that $Q_{\text {cal }}$ is calibrated digital numbers.

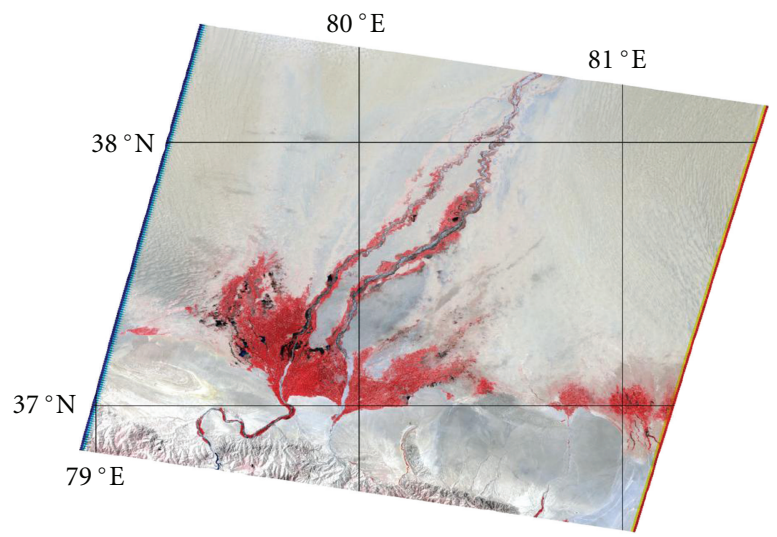

(a)

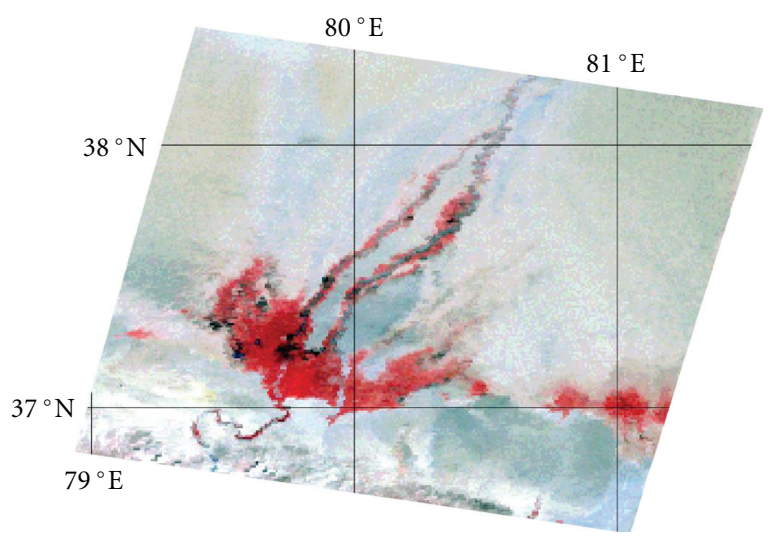

(b)

Figure 2: False color images of Landsat-7/ETM+ (R, B, G: bands 4, 3, and 2) (a) and Terra/MODIS (R, G, B: bands 7, 2, and 1) (b) over the Hotien Oasis in Taklimakan Desert observed on June 8, 2002. The geographic locations of the four corners (clockwise starting at the top left) of the image are UL $\left(38.45^{\circ} \mathrm{N}, 78.87^{\circ} \mathrm{E}\right)$, UR $\left(38.47^{\circ} \mathrm{N}, 81.70^{\circ} \mathrm{E}\right), \mathrm{LR}\left(36.49^{\circ} \mathrm{N}, 78.92^{\circ} \mathrm{E}\right)$, and $\mathrm{LL}\left(36.50^{\circ} \mathrm{N}, 81.68^{\circ} \mathrm{E}\right)$. In the false color images, yellow is sandy desert and sand dunes, gray is desert of stones and pebbles, white is rocks, red is farmlands and grasslands, and black is water of river and reservoir.

TABLE 6: Calibration constants of the TIR bands of Terra/MODIS data (MOD021KM, Collection 5) for converting SI to observed spectral radiance.

\begin{tabular}{ccc}
\hline Band & $\begin{array}{c}R_{\text {scale } \lambda} \\
\left(\mathrm{W} /\left(\mathrm{m}^{2} \cdot \mathrm{sr} \cdot \mu \mathrm{m}\right)\right)\end{array}$ & $R_{\text {offset } \lambda}$ \\
\hline 31 & 0.00084002200 & 1577.3397 \\
32 & 0.00072969760 & 1658.2212 \\
\hline
\end{tabular}

Note that: SI is scaled integer.

3.2. Conversion of Terra/MODIS Bands 31 and 32 Data to BT. Conversion of the scaled integer (SI) values of the Scientific Data Sets (SDSs) of Terra/MODIS Level 1B Version 5.0 products back to observed spectral radiance $\left(L_{\lambda}\right)$ requires the lower and upper limit of the original rescaling factors $R_{\text {scale }}$ and $R_{\text {offset }}$ written as attributes of SDSs. The pre-launch calibration constants of the TIR bands of Terra/MODIS $1 \mathrm{~km}$ spatial resolution data (MOD021KM, Collection 5) for converting SI to observed spectral radiance are shown in Table 6. The conversion equation [4] is

$$
\begin{gathered}
L_{\lambda}=R_{\text {scale } \lambda}\left(\mathrm{SI}_{\lambda}-R_{\text {offset } \lambda}\right), \\
R_{\text {scale } \lambda}=\frac{L_{\max \lambda}-L_{\min \lambda}}{32767}, \\
R_{\text {offset } \lambda}=-\frac{32767 \times L_{\min \lambda}}{L_{\max \lambda}-L_{\min \lambda}},
\end{gathered}
$$

where $L_{\lambda}$ is observed spectral radiance in $\mathrm{W} /\left(\mathrm{m}^{2} \cdot \mathrm{sr} \cdot \mu \mathrm{m}\right), \mathrm{SI}_{\lambda}$ is scaled integer value of 16 bits unsigned integer data in
Dimensionless, $L_{\min \lambda}$ is observed spectral radiance scaled to 0 in $\mathrm{W} /\left(\mathrm{m}^{2} \cdot \mathrm{sr} \cdot \mu \mathrm{m}\right), L_{\max } \lambda$ is observed spectral radiance scaled to $32767 \mathrm{in} \mathrm{W} /\left(\mathrm{m}^{2} \cdot \mathrm{sr} \cdot \mu \mathrm{m}\right), R_{\text {scale } \lambda}$ is radiance rescaling gain factor in $\mathrm{W} /\left(\mathrm{m}^{2} \cdot \mathrm{sr} \cdot \mu \mathrm{m}\right)$, and $R_{\text {offset } \lambda}$ is radiance rescaling offset factor in Dimensionless.

The data of the TIR bands 31 and 32 of Terra/MODIS can be converted from observed spectral radiance $\left(L_{\lambda}\right)$ to observed BT applying the Planck's law of blackbody radiation. The conversion equation [4] is

$$
T=\frac{h c / k \lambda}{\ln \left(2 h c^{2} /\left(L_{\lambda} \lambda^{5} \times 10^{-6}\right)+1\right)},
$$

where $T$ is observed BT in Kelvin, $h$ is Planck constant $\left(6.62606896 \times 10^{-34} \mathrm{~J} \cdot \mathrm{s}\right), \quad c$ is speed of light $(2.99792458 \times$ $\left.10^{+8} \mathrm{~m} / \mathrm{s}\right), k$ is Boltzmann constant $\left(1.3806504 \times 10^{-23} \mathrm{~J} / \mathrm{K}\right)$, $\lambda$ is center wavelength in meter, and $L_{\lambda}$ is observed spectral radiance in $\mathrm{W} /\left(\mathrm{m}^{2} \cdot \mathrm{sr} \cdot \mu \mathrm{m}\right)$.

From (2) and (4), the center wavelengths of the TIR band 6 of Landsat-7/ETM+ can be estimated as follows:

$$
\begin{gathered}
K_{1}=\frac{2 h c^{2}}{\lambda_{1}^{5} \times 10^{-6}} \Longleftrightarrow \lambda_{1}=11.2167 \mu \mathrm{m}, \\
K_{2}=\frac{h c}{k \lambda_{2}} \Longleftrightarrow \lambda_{2}=11.2326 \mu \mathrm{m}, \\
\bar{\lambda}=\frac{\left(\lambda_{1}+\lambda_{2}\right)}{2}=11.2247 \mu \mathrm{m} .
\end{gathered}
$$

The estimated center wavelength of the TIR band 6 of Landsat-7/ETM+ is nearly equal to the center wavelength 


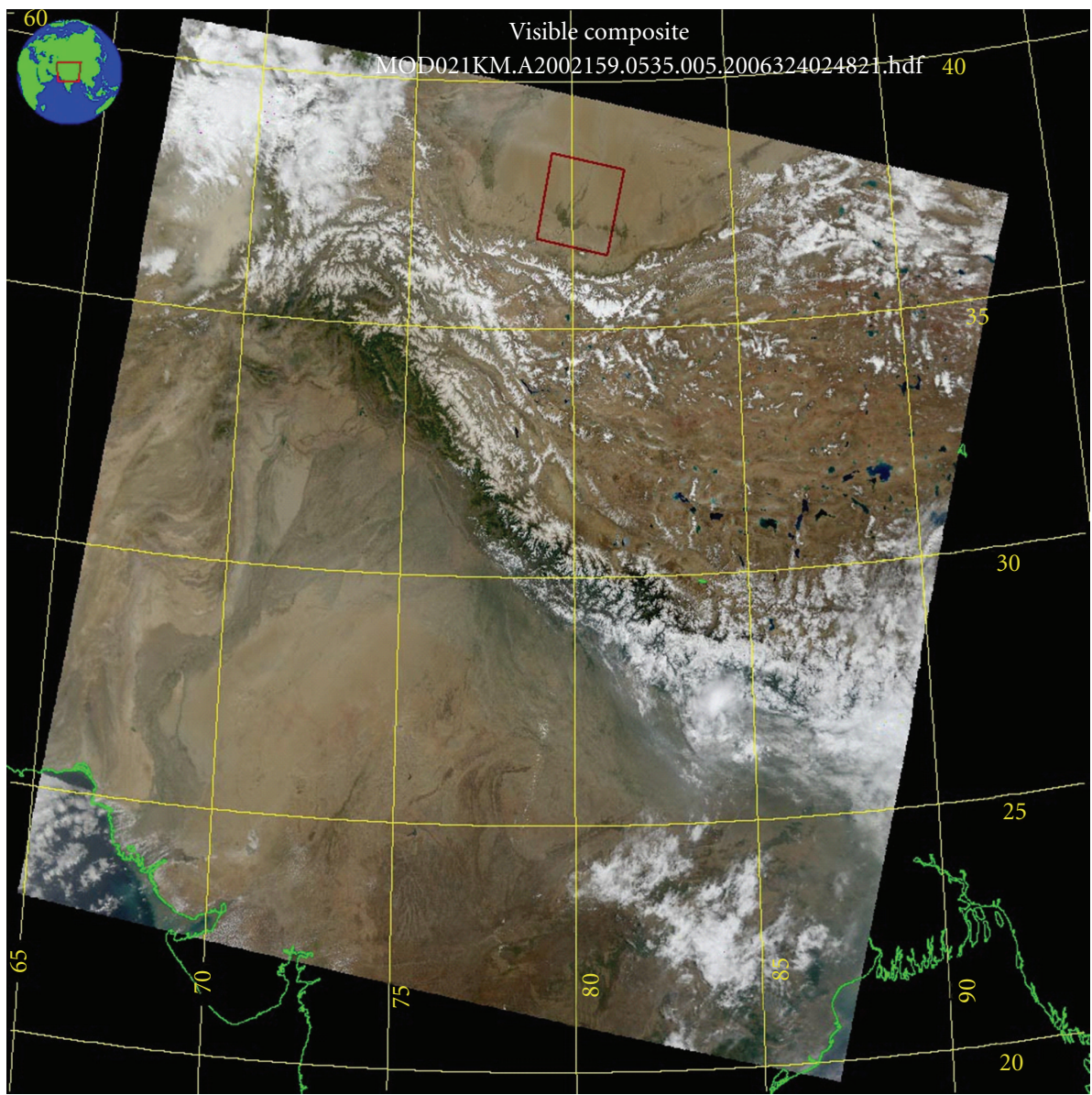

Figure 3: True color image of Terra/MODIS (R, G, B: bands 1, 4, and 3) observed at UTC 05:35 on June 8, 2002. The red rectangle indicates the observation area of Landsat-7/ETM+ on June 8, 2002 (Path-Row: 146-034).

obtained from the cumulative histogram at $50 \%$ of RSR as shown in Table 2.

\section{Results and Discussion}

4.1. Rough Analysis of the Entire BT of the Images. BT of Landsat-7/ETM+ band 6 and that of Terra/MODIS bands 31 and 32 were computed by (2) and (4), respectively. BT images over Hotien Oasis acquired on June 8, 2002 of Landsat7/ETM+ band 6, Terra/MODIS bands 31 and 32 are shown in Figure 4. The geographic locations of the four corners are same as those in Figure 2. From Figure 4 it is found that the range of $\mathrm{BT}$ is approximately $20-60^{\circ} \mathrm{C}$. In addition, BT of desert of Terra/MODIS band 32 image seems a little higher than the other images. An example of the surface temperature observed with a hand-held radiometer in the desert around the Hotien Oasis at 10:30-11:00 (local time) on September 26, 1992 is shown in Figure 5. The retrieved value seems to be reasonable in referring to these LSTs although the observation year and day are different.

4.2. Detailed Analysis of BT's Retrieved from the Data of Band 6 of ETM+ and MODIS Bands 31 and 32. For accurate comparison of BT's retrieved from the data of band 6 of ETM+ and MODIS bands 31 and 32, following data processing was performed:

(1) correction of geometric distortions of the data in reference to the ground control points which had been accumulated during the Japan-China Joint Study of Desertification; (2) resampling of MODIS data of $1 \mathrm{~km} \times 1 \mathrm{~km}$ size to make $900 \mathrm{~m} \times 900 \mathrm{~m}$ pixels so that each MODIS pixel contains exactly $225 \mathrm{ETM}+(60 \mathrm{~m} \times 60 \mathrm{~m})$ pixels; since the difference of the sizes of the original and resampled pixels is small the Nearest Neighborhood Method was adopted for resampling; (3) five clear pixels of MODIS were selected from each category of landcover within the area of ETM+ image; (4) for each of 20 landcover categories, statistical values such as mean, standard deviation, maximum and minimum values, ranges, and ratios of the number of samples belonging to $\mathrm{m}$ (mean) \pm 1 and $2 \sigma$ (standard deviation) of 20 categories were computed for each of $5 \mathrm{ETM}+$ images corresponding to 5 selected pixels of MODIS image; (5) the average values of the items listed above were computed from the above stated 5 ETM+ image samples and shown in Table 7. The means of MODIS Bands 31 and 32 were computed from 5 pixels of each landcover category. 


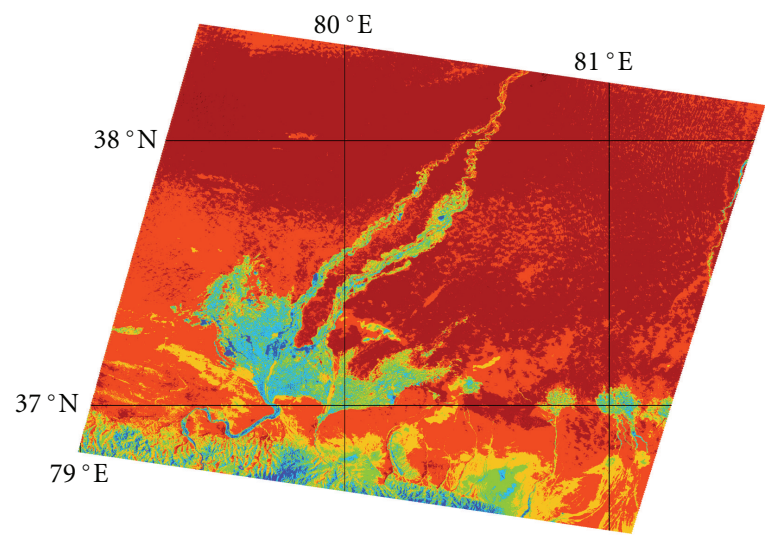

(a)

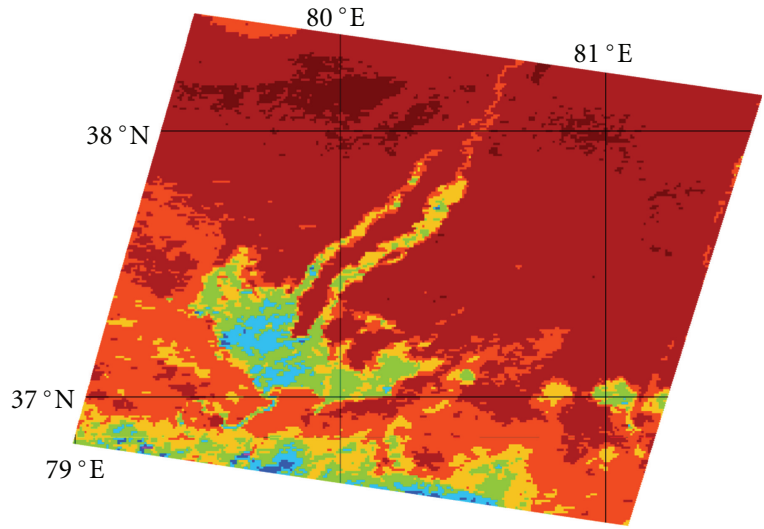

(b)

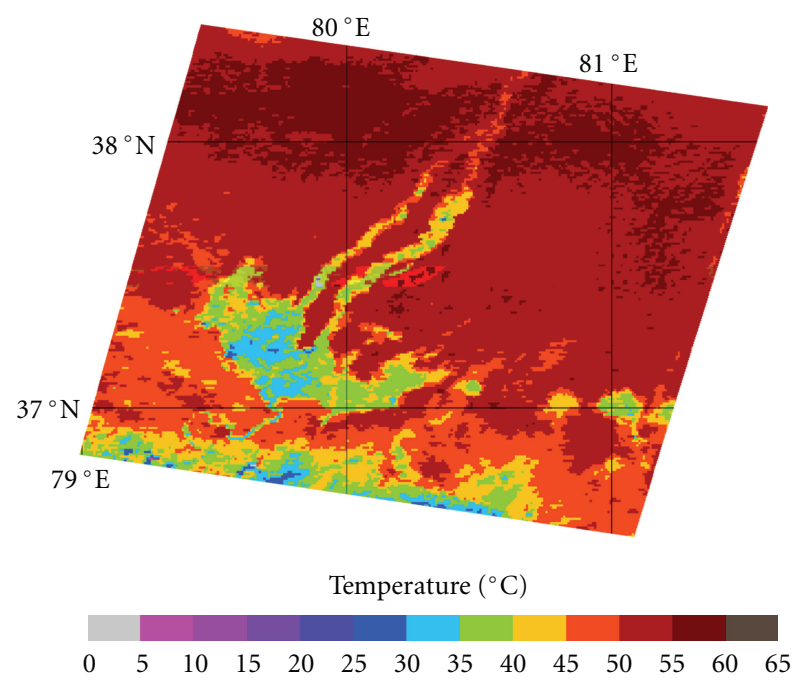

(c)

FIGURE 4: Brightness temperature images of Landsat-7/ETM+ band 6 (a), Terra/MODIS bands 31 (b), and 32 (c) over the Hotien Oasis in Taklimakan Desert observed on June 8, 2002. The geographic locations of the four corners are the same as in Figure 2.

Although it is clear from the table some noteworthy features of the BTs of ETM+ will be pointed out.

(A) Surprisingly large range for specific targets: $16.04^{\circ} \mathrm{C}$ for shading side of rocky hill and $14.04^{\circ} \mathrm{C}$ for the oasis farmland, while comparatively small range for a flat desert with the value of $2.25^{\circ} \mathrm{C}$. The reason of large range of the oasis farmland is due to the fact that subdivided farmlands are surrounded with tall wind and sand break forests. The low temperatures of the tree leaves and shadows of the forests contribute to the large range.

(B) Reflecting the large values of ranges, the shading side of rocky hill and the oasis farmland show large standard deviation. The oasis farmland shows the largest value of $2.88^{\circ} \mathrm{C}$ while the flat desert shows the smallest value of $0.45^{\circ} \mathrm{C}$. Since number of sample of MODIS is only 5 the standard deviation of MODIS data was not computed.

(C) As to BT the observation time of MODIS is nearer to the local noon than that of ETM+ by about $30 \mathrm{~min}$ - utes therefore the BTs of MODIS is generally higher than those of ETM+ except sunny side of rocky hills and the beach of the upper reach of the large river which have slightly higher BTs than MODIS. The reason is that the slope of the sunny side of these places with a favorable orientation for the sun received more sun radiation and was warmed up than other places.

(D) Among the BTs of ETM+ for different landcover categories the top 3 ranking BTs of the target in the descending order is (1) sandy desert and sand dunes, (2) grassland and river beach of the lower reach of the large river, and (3) desert of stone and pebble, and rocky hill (sunny side) while the top 3 bottom ranking in the ascending order is (1) reservoir, (2) oasis farmland with scattered bare land, and (3) rocky hill with dry vegetation (shading side).

(E) As to the distribution of the samples of ETM+ the distribution for the following categories shows semi-normal distribution: sunny side rocky hills, oasis farmland with scattered bright bare land and grass land near the upper reach of the large river. 
TABLE 7: Summary of statistical analysis of the brightness temperature samples of ETM+ corresponding to one pixel of MODIS. In the table $\# 1 \sigma$ and $\# 2 \sigma$ are the ratio $(\%)$ of the numbers of samples of ETM+ in $(\mathrm{m} \pm 1 \sigma)$ and $(\mathrm{m} \pm 2 \sigma)$, respectively, in the area of one pixel of MODIS.

\begin{tabular}{|c|c|c|c|c|c|c|c|c|c|}
\hline \multirow{3}{*}{ Name } & \multirow{2}{*}{\multicolumn{7}{|c|}{$\begin{array}{c}\text { ETM+ } \\
\text { Band } 6\end{array}$}} & \multicolumn{2}{|c|}{ MODIS } \\
\hline & & & & & & & & \multirow{2}{*}{$\begin{array}{c}\text { Band } 31 \\
\text { Mean }\end{array}$} & \multirow{2}{*}{$\begin{array}{c}\text { Band } 32 \\
\text { Mean }\end{array}$} \\
\hline & Mean & Std.D. & Min. & Max. & Range & $\# 1 \sigma \%$ & $\# 2 \sigma \%$ & & \\
\hline Desert (flat) & 51.55 & 0.45 & 50.37 & 52.62 & 2.25 & 64.11 & 97.04 & 53.73 & 54.63 \\
\hline Area of small sand dune & 50.21 & 0.58 & 48.76 & 51.79 & 3.03 & 61.22 & 95.89 & 52.22 & 53.28 \\
\hline Area of large sand dune & 50.63 & 0.50 & 48.60 & 52.79 & 4.19 & 64.78 & 96.91 & 53.79 & 54.62 \\
\hline Desert of stone and pebble (bright) & 45.70 & 0.54 & 44.01 & 46.96 & 2.95 & 77.53 & 96.80 & 47.20 & 47.82 \\
\hline Desert of stone and pebble (dark) & 45.47 & 0.67 & 43.92 & 47.14 & 3.22 & 61.13 & 96.33 & 46.24 & 46.71 \\
\hline Rocky hill (sunny side) & 45.11 & 1.67 & 39.92 & 49.60 & 9.68 & 67.66 & 96.42 & 44.61 & 45.14 \\
\hline Rocky hill (shading side) & 35.28 & 2.80 & 29.66 & 45.70 & 16.04 & 71.64 & 95.13 & 39.19 & 39.25 \\
\hline Rocky hill with dry vegetation (sunny side) & 40.83 & 1.90 & 34.54 & 45.36 & 10.82 & 69.78 & 95.62 & 40.01 & 40.25 \\
\hline Rocky hill with dry vegetation (shading side) & 33.59 & 1.65 & 29.32 & 39.03 & 9.71 & 63.89 & 97.07 & 36.29 & 36.21 \\
\hline Oasis farmland & 37.00 & 2.88 & 30.59 & 44.63 & 14.04 & 66.42 & 96.18 & 38.73 & 38.43 \\
\hline Oasis farmland with scattered bright bare land & 32.65 & 2.31 & 29.04 & 41.08 & 12.04 & 70.49 & 95.33 & 34.41 & 34.17 \\
\hline Oasis farmland withscattered dark bare land & 32.52 & 2.20 & 28.64 & 38.65 & 10.01 & 63.02 & 97.42 & 33.59 & 33.45 \\
\hline Oasis farmland with paved roads & 40.30 & 2.09 & 33.63 & 45.07 & 11.44 & 67.18 & 96.11 & 41.30 & 41.48 \\
\hline Urban area with paved roads & 42.05 & 1.39 & 37.75 & 45.59 & 7.84 & 67.62 & 96.36 & 43.08 & 43.11 \\
\hline Grassland near lower reach of large river & 48.59 & 2.20 & 42.67 & 51.96 & 9.29 & 64.56 & 97.47 & 50.98 & 50.98 \\
\hline Grassland near upper reach of large river & 40.70 & 2.08 & 35.78 & 45.66 & 9.88 & 68.44 & 96.07 & 40.98 & 41.16 \\
\hline River beach of lower reach of large river & 48.63 & 1.64 & 41.53 & 51.38 & 9.85 & 70.09 & 96.67 & 49.82 & 50.36 \\
\hline River beach of upper reach of large river & 41.92 & 1.07 & 37.71 & 45.24 & 7.53 & 76.96 & 94.98 & 41.22 & 41.84 \\
\hline Reservoir & 23.84 & 0.98 & 22.50 & 30.71 & 8.21 & 77.91 & 96.40 & 26.89 & 26.17 \\
\hline Total (Mean) & 41.40 & 1.56 & 37.31 & 45.84 & 8.53 & 68.11 & 96.33 & 42.86 & 43.11 \\
\hline
\end{tabular}

m: mean, $\sigma$ : standard deviation, unit of BT: ${ }^{\circ} \mathrm{C}, \# 1 \sigma=\mathrm{m} \pm 1 \sigma, \# 2 \sigma=\mathrm{m} \pm 2 \sigma$, samples of ETM+: 225.

4.3. Linearity between BT of Landsat-7/ETM+ and Terra/ MODIS. The relations between BT of Landsat-7/ETM+ band 6 and Terra/MODIS bands 31 and 32 are shown in Figures 6 and 7, respectively. In these figures, it can be seen that BT of Landsat-7/ETM+ and that of Terra/MODIS bands 31 and 32 indicate high correlations, and the correlation coefficients are approximately 0.97 . The regression equations between Landsat-7/ETM+ band 6 and Terra/MODIS band 31 and 32 are

$$
\begin{array}{ll}
T_{31}=0.9625 \times T_{6}+3.0097 & (\text { for Terra/MODIS band 31) }, \\
T_{32}=1.0140 \times T_{6}+1.1312 & (\text { for Terra/MODIS band 32) } .
\end{array}
$$

4.4. Effects of the Emissivity of the Targets and the Atmosphere to the BTs of MODIS Bands 31 and 32. An attempt is made to estimate the effects of emissivity of the targets and the atmosphere to the BTs by introducing two adjustment parameters $\alpha$ and $\beta$ into (2) and (4) as are shown in (7) and (8), respectively.

$$
\begin{gathered}
T_{6}=\frac{K_{2}}{\ln \left(\left(\alpha \beta K_{1} / L_{\lambda}\right)+1\right)}, \\
T=\frac{h c / k \lambda}{\ln \left(\alpha \beta 2 h c^{2} /\left(L_{\lambda} \lambda^{5} \times 10^{-6}\right)+1\right)}
\end{gathered}
$$

where $\alpha$ is adjustment parameter to atmospheric effect, $\beta$ is adjustment parameter to emissivity effect.

The land cover classification image over the study area is shown in Figure 8. The emissivity and pixel number of each category of the TIR bands of Terra/MODIS is shown in Table 8. The values of emissivity are taken from the paper by Wan [7]. The large part of the study area is occupied with bare land and rock, and the overall emissivity of the study area to Terra/MODIS bands 31 and 32 are 0.967 and 0.973 , respectively.

The estimation result of overall BT of the study area is shown in Table 9. The value of $\alpha$ is function of the extinction coefficient of the atmosphere which is influenced by the amount of water vapor, dust, and minute sands blown up by the dust devil which frequently occurs in the area. Under such condition, it is difficult to obtain exact value of the extinction coefficient therefore two values of 1.000 and 1.032 for $\alpha$ are adopted in the computation. As to the value of $\beta$ of ETM + band 6, the average value of those of MODIS band 31 and 32 is adopted.

From Table 9, it can be concluded that the difference of BT between Landsat-7/ETM+ and Terra/MODIS is the observation time difference. On the other hand, it is concluded that in the difference of BT of Terra/MODIS bands 31 and 32 , the atmospheric effect is approximately $0.21^{\circ} \mathrm{C}$ and the emissivity effect is approximately $0.35^{\circ} \mathrm{C}$. 


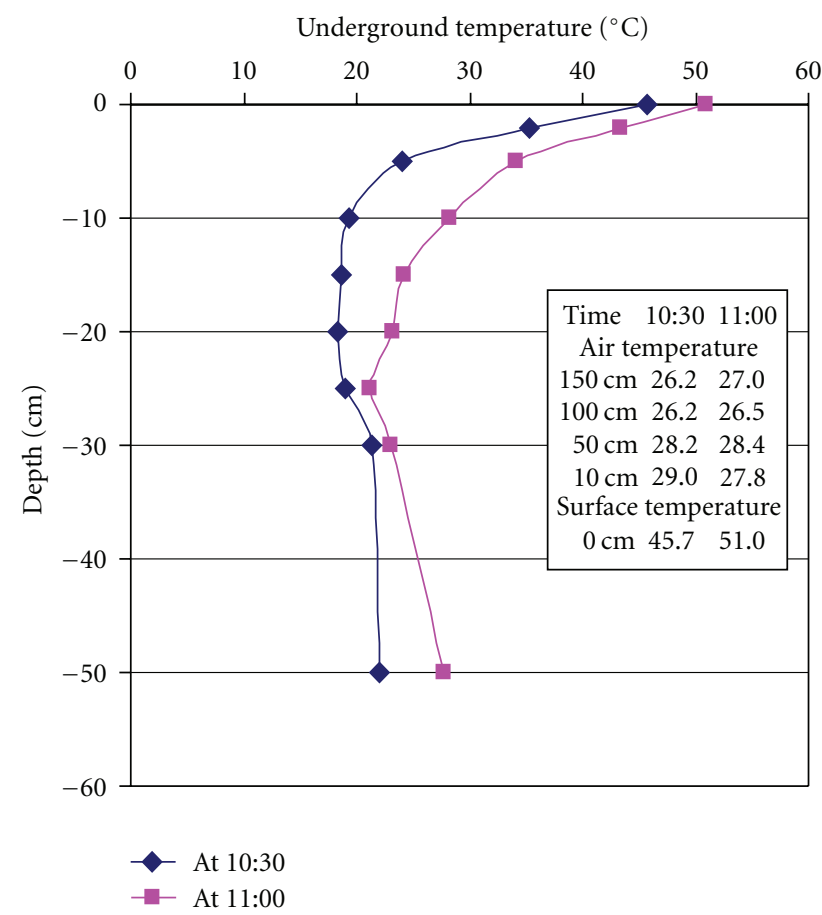

FIGURE 5: Examples of the surface and underground temperature together with the near surface air temperature distribution at 10:30 and 11:00 local time. The data at 10:30 were acquired at a flat area with sparsely grown short tamalix and reed while those of 11:00 were acquired at the top of a small sand dune of several meters height with scarcely grown short reed in Taklimakan Desert. The height of both places is $1200 \mathrm{~m}$ above sea level.

TABLE 8: The values of referred emissivity of the TIR bands of Terra/MODIS.

\begin{tabular}{|c|c|c|c|c|c|c|}
\hline Legend & $\varepsilon_{31}$ & $\varepsilon_{32}$ & Pixels & Ratio\% & $\Delta \varepsilon_{31}$ & $\Delta \varepsilon_{32}$ \\
\hline Water & 0.992 & 0.988 & 7200 & 0.02 & 0.00015 & 0.00015 \\
\hline Evergreen needleleaf forest & 0.987 & 0.989 & 0 & 0.00 & 0.00000 & 0.00000 \\
\hline Evergreen broadleaf forest & 0.981 & 0.984 & 0 & 0.00 & 0.00000 & 0.00000 \\
\hline Deciduous needleleaf forest & 0.987 & 0.989 & 0 & 0.00 & 0.00000 & 0.00000 \\
\hline Deciduous broadleaf forest & 0.981 & 0.984 & 0 & 0.00 & 0.00000 & 0.00000 \\
\hline Mixed forest & 0.981 & 0.984 & 0 & 0.00 & 0.00000 & 0.00000 \\
\hline Woody savannas & 0.982 & 0.985 & 0 & 0.00 & 0.00000 & 0.00000 \\
\hline Savannas & 0.983 & 0.987 & 2700 & 0.01 & 0.00006 & 0.00006 \\
\hline Closed shrubland & 0.983 & 0.980 & 284400 & 0.61 & 0.00603 & 0.00601 \\
\hline Open shrubland & 0.972 & 0.976 & 3760082 & 8.11 & 0.07884 & 0.07916 \\
\hline Grassland & 0.983 & 0.987 & 1763562 & 3.80 & 0.03739 & 0.03755 \\
\hline Cropland & 0.983 & 0.987 & 524245 & 1.13 & 0.01112 & 0.01116 \\
\hline Bare soil and rocks & 0.965 & 0.972 & 40008359 & 86.30 & 0.83281 & 0.83885 \\
\hline Urban and built-up & 0.970 & 0.976 & 8100 & 0.02 & 0.00017 & 0.00017 \\
\hline Total & - & - & 46358648 & 100.00 & 0.96657 & 0.97312 \\
\hline
\end{tabular}

Note: $\Delta \varepsilon=\varepsilon \times$ ratio. 


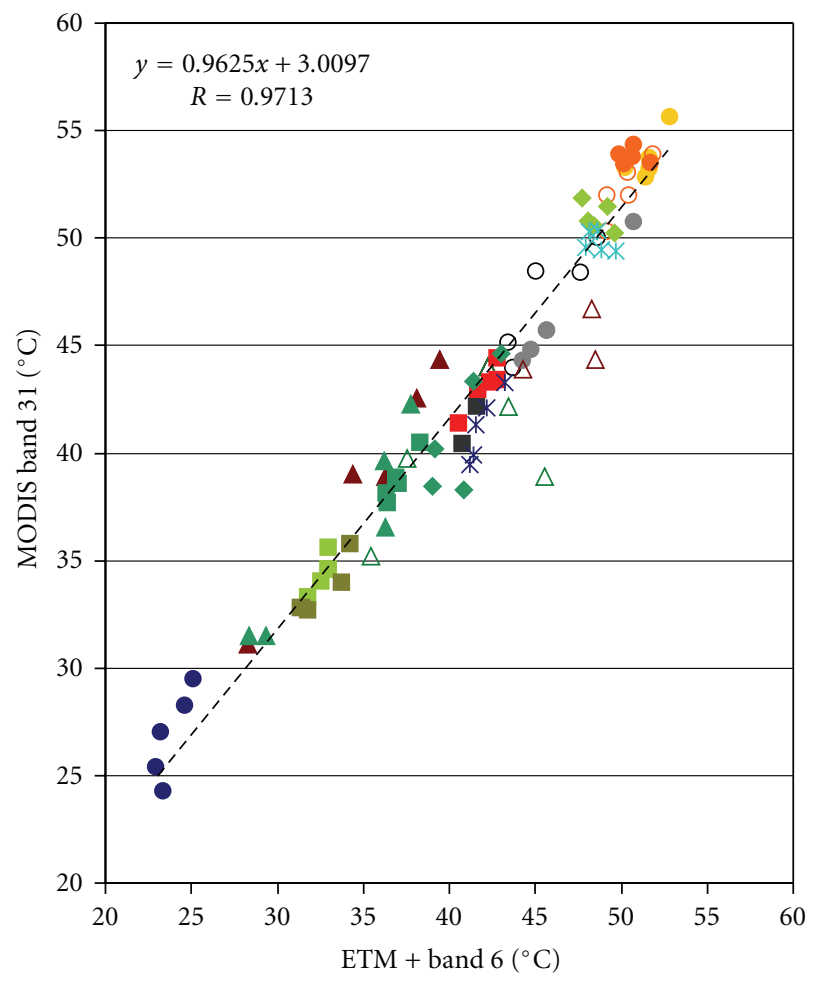

- Desert (flat)

- Area of small sand dune

- Area of large sand dune

- Desert of stone and pebble (bright)

- Desert of stone and pebble (dark)

$\Delta \quad$ Rocky hill (sunny side)

- Rocky hill (shading side)

$\Delta \quad$ Rocky hill with dry vegetation (sunny side)

- Rocky hill with dry vegetation (shading side)

- Oasis farmland

- Oasis farmland with scattered bright bare land

- Oasis farmland with scattered dark bare land

- Oasis farmland with paved roads

- Urban area with paved roads

- Grassland near the lower reach of the large river

- Grassland near the upper reach of the large river

* River beach of the lower reach of the large river

* River beach of the upper reach of the large river

- Reservoir

- - - Linear

FIGURE 6: Comparison between the brightness temperatures obtained from band 6 of Landsat-7/ETM+ and Terra/MODIS band 31.

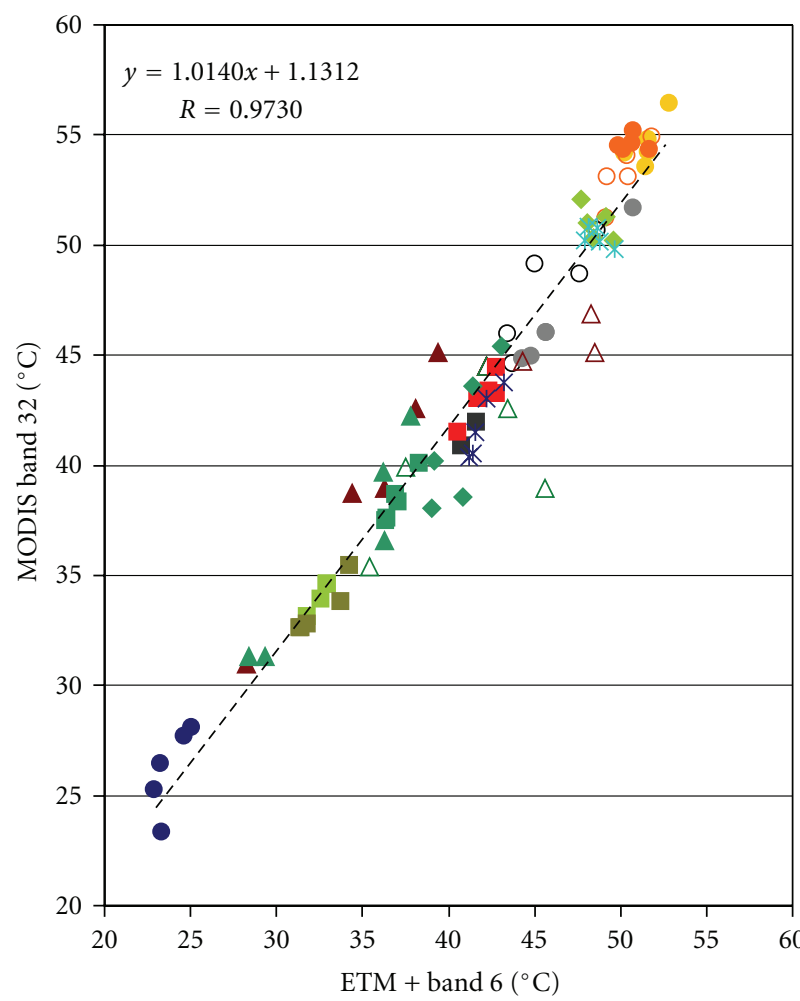

Desert (flat)

- Area of small sand dune

- Area of large sand dune

- Desert of stone and pebble (bright)

- Desert of stone and pebble (dark)

$\Delta \quad$ Rocky hill (sunny side)

\ Rocky hill (shading side)

$\Delta \quad$ Rocky hill with dry vegetation (sunny side)

$\Delta \quad$ Rocky hill with dry vegetation (shading side)

- Oasis farmland

- Oasis farmland with scattered bright bare land

- Oasis farmland with scattered dark bare land

- Oasis farmland with paved roads

- Urban area with paved roads

- Grassland near the lower reach of the large river

- Grassland near the upper reach of the large river

* River beach of the lower reach of the large river

* River beach of the upper reach of the large river

- Reservoir

--- Linear

FIGURE 7: Comparison between the brightness temperatures obtained from band 6 of Landsat-7/ETM+ and Terra/MODIS band 32. 
TABLE 9: The values of various factors adopted in the evaluation of the effects of emissivity and atmosphere to the value of brightness temperatures.

\begin{tabular}{|c|c|c|c|c|c|c|c|}
\hline $\begin{array}{l}\text { Adjustment parameters } \\
\alpha \text { and } \beta\end{array}$ & $\begin{array}{c}L_{6} \\
\left(\mathrm{~W} /\left(\mathrm{m}^{2} \cdot \mathrm{sr} \cdot \mu \mathrm{m}\right)\right)\end{array}$ & $\begin{array}{c}L_{31} \\
\left(\mathrm{~W} /\left(\mathrm{m}^{2} \cdot \mathrm{sr} \cdot \mu \mathrm{m}\right)\right)\end{array}$ & $\begin{array}{c}L_{32} \\
\left(\mathrm{~W} /\left(\mathrm{m}^{2} \cdot \mathrm{sr} \cdot \mu \mathrm{m}\right)\right)\end{array}$ & $\begin{array}{c}\mathrm{BT}_{6} \\
{ }^{\circ} \mathrm{C} \\
\end{array}$ & $\begin{array}{c}\mathrm{BT}_{31} \\
{ }^{\circ} \mathrm{C}\end{array}$ & $\begin{array}{c}\mathrm{BT}_{32} \\
{ }^{\circ} \mathrm{C}\end{array}$ & $\begin{array}{c}\mathrm{BT}_{31}-\mathrm{BT}_{32} \\
{ }^{\circ} \mathrm{C} \\
\end{array}$ \\
\hline $\begin{array}{l}\alpha=1.000 \\
\beta=1.000\end{array}$ & 12.35 & 12.95 & 11.92 & 47.02 & 49.01 & 49.57 & -0.56 \\
\hline $\begin{array}{l}\alpha=1.000 \\
\beta_{6}=0.970 \\
\beta_{31}=0.967 \\
\beta_{32}=0.973\end{array}$ & 12.73 & 13.40 & 12.25 & 49.44 & 51.69 & 51.90 & -0.21 \\
\hline $\begin{array}{l}\alpha=1.032 \\
\beta_{6}=1.000 \\
\beta_{31}=1.000 \\
\beta_{32}=1.000\end{array}$ & 11.96 & 12.55 & 11.55 & 44.56 & 46.57 & 46.91 & -0.35 \\
\hline $\begin{array}{l}\alpha=1.032 \\
\beta_{6}=0.970 \\
\beta_{31}=0.967 \\
\beta_{32}=0.973\end{array}$ & 12.34 & 12.98 & 11.87 & 46.94 & 49.21 & 49.21 & 0.00 \\
\hline
\end{tabular}

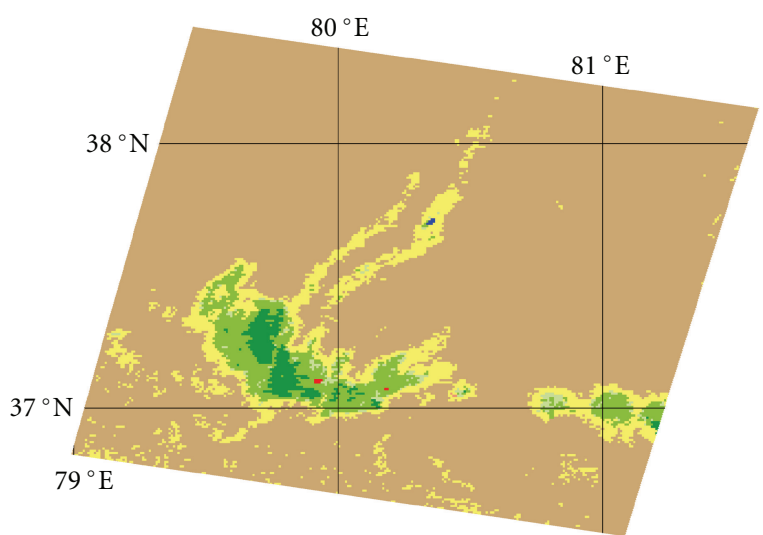

Water
Savannas
Closed shrubland
Open shrubland
Grassland

FIGURE 8: Land cover classification image [16]. The geographic locations of the four corners are the same as in Figure 2.

\section{Conclusion}

The result of the analysis lead to the following conclusions

(1) good linear relationship between the retrieved BT from the data of Landsat-7/ETM+ band 6 and those of Terra/MODIS bands 31 and 32;

(2) BT retrieved from the data of Terra/MODIS is slightly higher than that of Landsat-7/ETM+, however considering the observation time of Terra/MODIS is approximately 30 minutes nearer to the noon, it can be concluded that the value of BT of Terra/MODIS will be equal to that of Landsat-7/ETM+ if adjustment for the observation time difference is made;

(3) comparing of the retrieved BT of the targets from the observed data of Terra/MODIS band 31 and 32, the values of band 31 are slightly higher than that of band 32 over the water while with opposite trend over the desert and vegetated area;

(4) the standard deviation and range of BT of ETM+ corresponding to one pixel of MODIS are $0.45^{\circ} \mathrm{C}$, $2.25^{\circ} \mathrm{C}$ for a flat area of desert while respective values of the oasis farmland and shading side of rocky hill amount to $2.88^{\circ} \mathrm{C}, 14.04^{\circ} \mathrm{C}$, and $2.80^{\circ} \mathrm{C}, 16.04^{\circ} \mathrm{C}$.

\section{Acknowledgments}

Authors' sincere gratitude is due to three anonymous reviewers for their very precise comments and valuable suggestions. They are also very grateful to NASA for allowing them to use MODIS data freely.

\section{References}

[1] G. Chander, D. J. Meyer, and D. L. Helder, "Cross calibration of the landsat-7 ETM+ and EO-1 ALI sensor," IEEE Transactions on Geoscience and Remote Sensing, vol. 42, no. 12, pp. 28212831, 2004.

[2] NASA's Goddard Space Flight Center, "Landsat 7 Science Data Users Handbook-Data Products," http://landsathandbook.gsfc.nasa.gov/pdfs/Landsat7_Handbook.pdf.

[3] Z. Wan, Y. Zhang, Q. Zhang, and Z. L. Li, "Validation of the land-surface temperature products retrieved from terra moderate resolution imaging spectroradiometer data," Remote Sensing of Environment, vol. 83, no. 1-2, pp. 163-180, 2002.

[4] Members of the MODIS Characterization Support Team, MODIS Level $1 B$ Product User's Guide, NASA/Goddard Space Flight Center, Greenbelt, Md, USA, December 2003, http://mcst.gsfc.nasa.gov/l1b. 
[5] S. Liang, H. Fang, M. Chen et al., "Validating MODIS land surface reflectance and albedo products: methods and preliminary results," Remote Sensing of Environment, vol. 83, no. 1-2, pp. 149-162, 2002.

[6] N. Rochdi and R. Fernandes, "Intercalibration of vegetation indices from landsat etm + and modis $500 \mathrm{~m}$ data for lai mapping," Technical Note 3, pp. 1-11, Geomantics, Canada, 2008.

[7] Z. Wan, "New refinements and validation of the MODIS landsurface temperature/emissivity products," Remote Sensing of Environment, vol. 112, no. 1, pp. 59-74, 2008.

[8] Z. Wan, Y. Zhang, Q. Zhang, and Z. L. Li, "Quality assessment and validation of the MODIS global land surface temperature," International Journal of Remote Sensing, vol. 25, no. 1, pp. 261-274, 2004.

[9] J. M. Galve, C. Coll, V. Caselles, and E. Valor, "An atmospheric radiosounding database for generating land surface temperature algorithms," IEEE Transactions on Geoscience and Remote Sensing, vol. 46, no. 5, pp. 1547-1557, 2008.

[10] J. Storey, P. Scaramuzza, G. Schmidt, and J. Barsi, "Landsat 7 scan line corrector-off gap-filled product development," in Proceedings of Pecora 16th Global Priorities in Land Remote Sensing, American Society for Photogrammetry and Remote Sensing, Sioux Falls, SD, USA, 2005.

[11] T. Ishiyama, N. Saito, S. Fujikawa, K. Ohkawa, and S. Tanaka, "Ground surface conditions of oases around the Taklimakan Desert," Advances in Space Research, vol. 39, no. 1, pp. 46-51, 2007.

[12] A. Buhe, K. Tsuchiya, M. Kaneko, N. Ohtaishi, and M. Halik, "Land conver of oases and forest in XinJiang, China retrieved from ASTER data," Advances in Space Research, vol. 39, no. 1, pp. 39-45, 2007.

[13] Y. Oguro, S. Takeuchi, and K. Tsuchiya, "Development of environmental dataset of Taklamakan Desert by TERRA/AQUA MODIS data," in Proceedings of the 26th Asian Conference on Remote Sensing (ACRS '05), p. 22, Hanoi, Vietnam, November 2005.

[14] K. Tsuchiya and Y. Oguro, "Observation of large fixed sand dunes of Taklimakan Desert using satellite imagery," Advances in Space Research, vol. 39, no. 1, pp. 60-64, 2007.

[15] G. Chander, B. L. Markham, and D. L. Helder, "Summary of current radiometric calibration coefficients for landsat MSS, TM, ETM+, and EO-1 ALI sensors," Remote Sensing of Environment, vol. 113, no. 5, pp. 893-903, 2009.

[16] M. C. Hansen, R. S. Defries, J. R. G. Townshend, and R. Sohlberg, "Global land cover classification at $1 \mathrm{~km}$ spatial resolution using a classification tree approach," International Journal of Remote Sensing, vol. 21, no. 6-7, pp. 1331-1364, 2000 . 

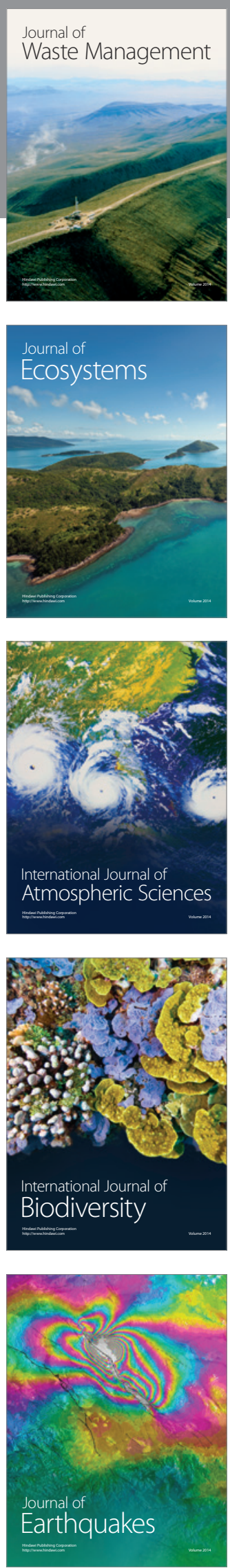
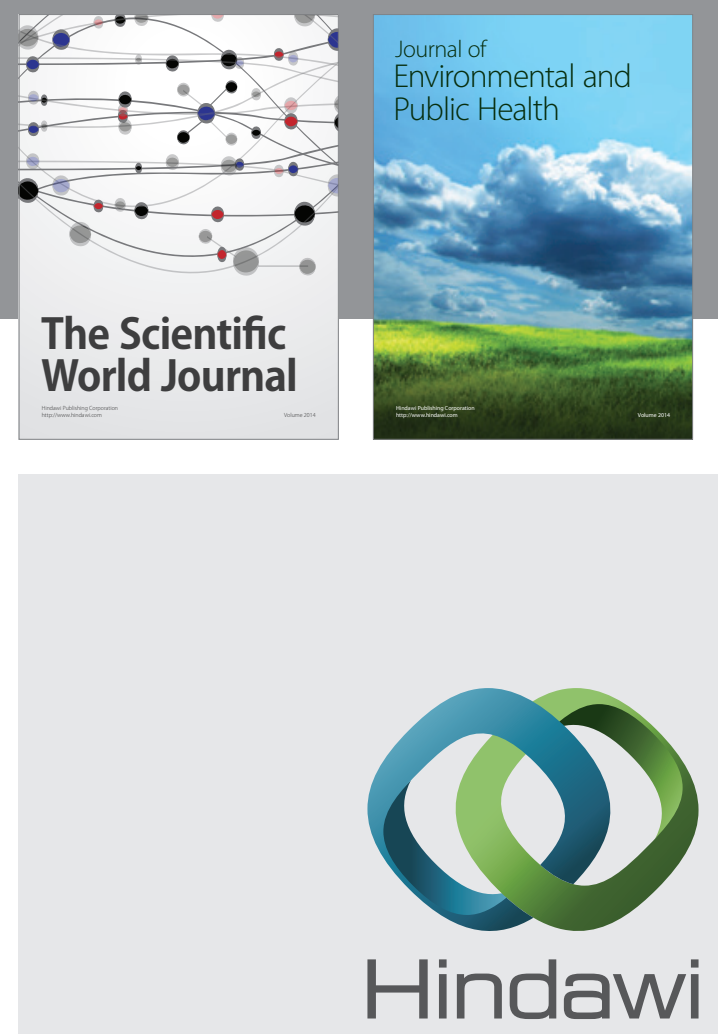

Submit your manuscripts at

http://www.hindawi.com
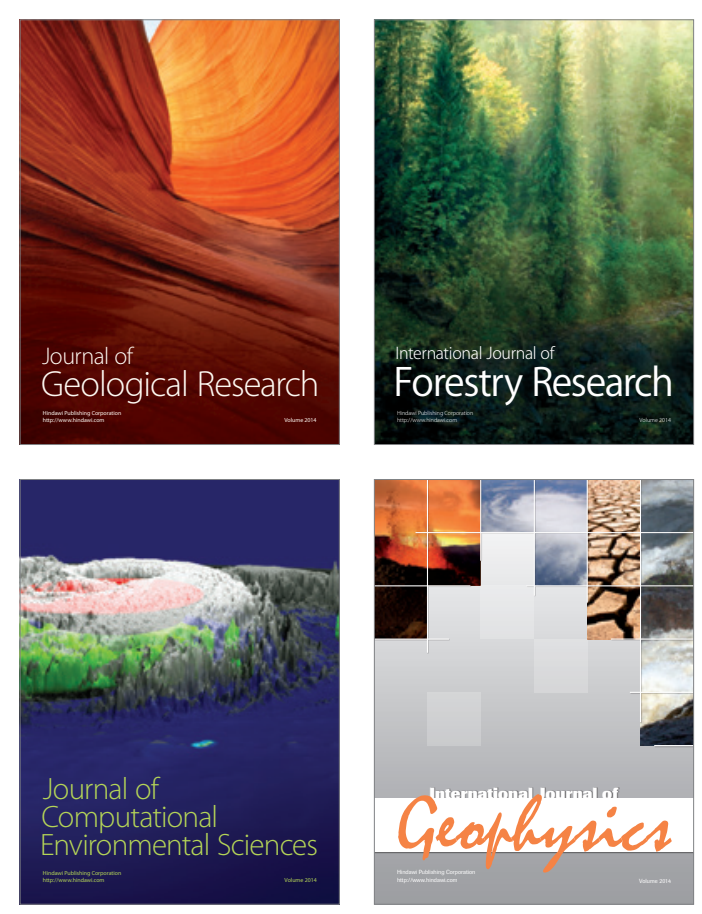
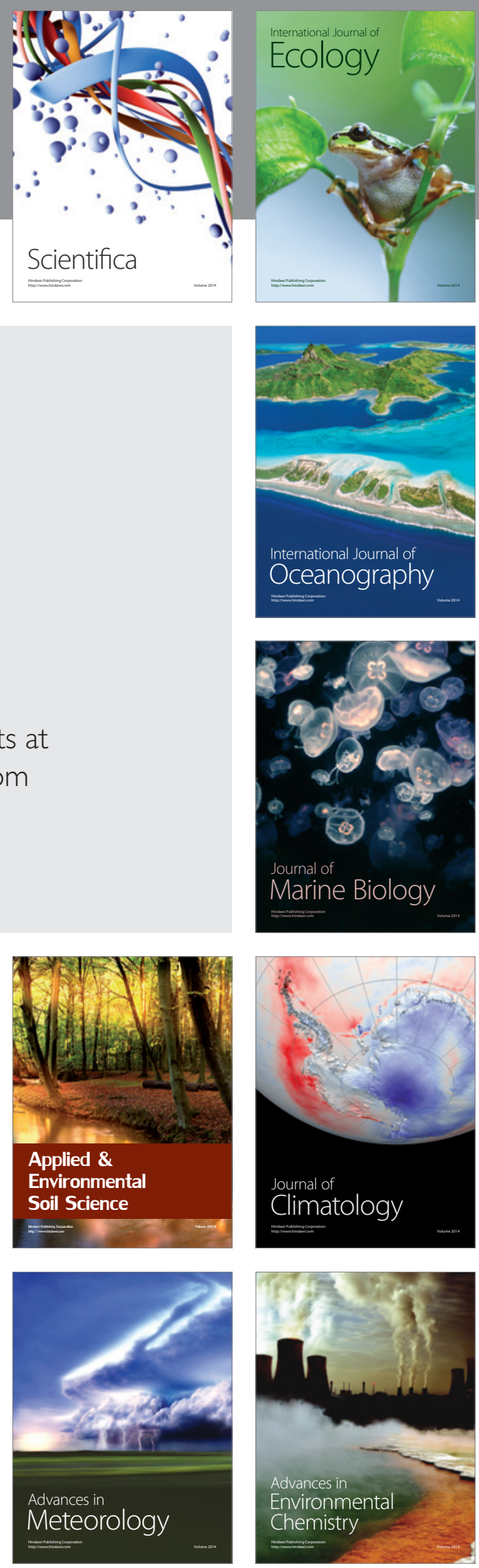